\title{
First report of Phaeosphaeriopsis glaucopunctata as the cause of leaf spot and necrosis on Ruscus aculeatus in Australia
}

\author{
H. Golzar • C. Wang
}

Received: 6 February 2011 / Accepted: 14 November 2011 / Published online: 27 November 2011

(C) Australasian Plant Pathology Society Inc. 2011

\begin{abstract}
Brown leaf spot and foliage necrosis were observed on Butcher's Broom (Ruscus aculeatus) in northeastern Perth, Western Australia in 2010. Based on disease symptoms, the morphological characteristics of the isolated fungus, a pathogenicity test and the sequence of the internal transcribed spacer (ITS) region, Phaeosphaeriopsis glaucopunctata was identified. This is the first report of $P$. glaucopunctata causing leaf spot and foliage necrosis on Ruscus aculeatus in Australia.
\end{abstract}

\section{Keywords Phaeosphaeriopsis $\cdot$ Ruscus .}

Leaf spot and foliage necrosis

Butcher's Broom, Ruscus aculeatus (family Asparagaceae), is an evergreen, perennial shrub native to western and southern Europe, northwest Africa, and southwest Asia. Paraphaeosphaeria glauco-punctata has been reported as the causal organism of leaf spot and necrosis on Ruscus (Camara et al. 2001; Checa et al. 2002). However, recently $P$. glaucopunctata was transferred to the genus Phaeosphaeriopsis and described as Phaeosphaeriopsis glaucopunctata (http://www.indexfungorum.org/names/ Names.asp.). Phaeosphaeriopsis species are found on Agavaceae from which $P$. agavensis, $P$. nolinae, $P$. obtusispora and $P$. amblyspor have been reported (Camara et al. 2003).

Disease symptoms were observed on $R$. aculeatus in the northeastern region of Perth, Western Australia in 2010.

H. Golzar $(\bowtie) \cdot$ C. Wang

Department of Agriculture and Food Western Australia,

3 Baron-Hay Court,

South Perth, WA 6151, Australia

e-mail: hossein.golzar@agric.wa.gov.au
Symptoms appeared as discoloured lesions, $2 \mathrm{~mm}$ in diam that developed into larger brown necrotic lesions (4-6 mm in diam.). In severe cases, lesions coalesced to form large necrotic areas and in some cases, complete leaf death (Fig. 1a). Pycnidia and pseudothecial ascomata were embedded in host tissue or erumpent through the epidermis (Fig. 1b). Twenty leaf specimens were excised from lesions and surface-sterilised by immersion in a $1.25 \%$ aqueous solution of sodium hypochlorite for $2 \mathrm{~min}$, rinsed in sterile water and dried in a laminar flow cabinet. The leaf pieces were then either a) placed on potato dextrose agar (PDA) and incubated at $22 \pm 3^{\circ} \mathrm{C}$ for 7 days, with fungal colonies subsequently sub-cultured onto PDA and then singlespored to obtain pure cultures; or b) placed in trays on moist filter paper and incubated at $25^{\circ} \mathrm{C}$ with a $12-\mathrm{h}$ dark and light cycle for 2 weeks. Coniothyrium-like anamorph and Phaeosphaeriopsis sp. (teleomorph) were consistently isolated and the growth rate, colony morphology and morphological characteristics of the fungal isolates were determined. The fungal colonies were pale grey, turning brown with age, and grew slowly (approximately $2 \mathrm{~mm}$ per day at 22 to $24^{\circ} \mathrm{C}$ ) on PDA. Pseudothecia were scattered or aggregated and formed sub-epidermally, often with no conspicuous neck; dark brown in colour, globose to ovoid, ostiolate $170-250 \mu \mathrm{m}$ in diam. Asci bitunicate, cylindrical to clavate, $65-80 \times 12-16 \mu \mathrm{m}$, ascospores cylindrical to clavate, rounded at ends with 4 septa slightly constricted, 14-20×3.5-5 $\mathrm{mm}$ in diam. (Fig. 2a, b). Pycnidia were immersed in the culture, scattered or in groups, dark brown, subglobose, ostiolate, $125-210 \mu \mathrm{m}$ in diam. Conidiogenous cells globose to ampulliform, conidia unicellular, thickwalled, smooth, globose to slightly reniform, rounded ends, pale gray and turning olivaceous brown at the maturity, 6$10 \times 3-5 \mu \mathrm{m}$ (Fig. 2c). Both the cultural and morphological 


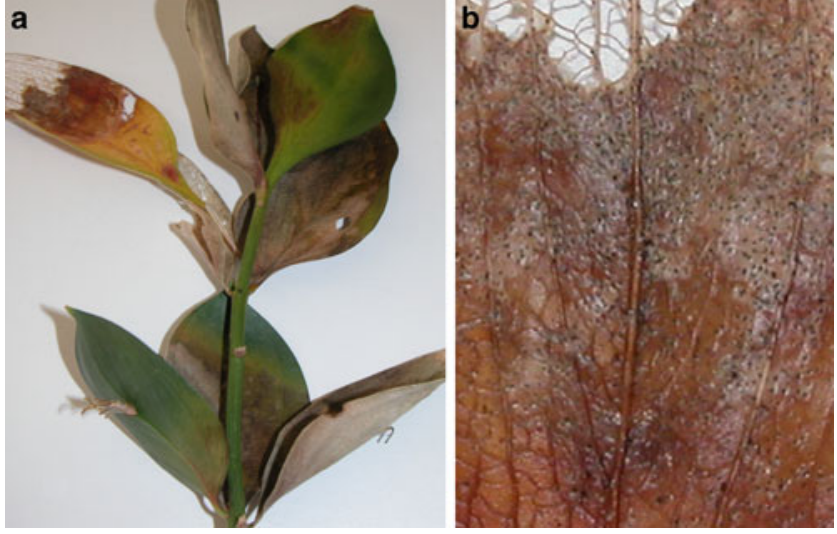

Fig. 1 Ruscus aculeatus, leaves showing brown necrotic areas (a) and advanced symptoms with fruiting bodies of Phaeosphaeriopsis glaucopunctata (b)

characteristics of the isolates were similar to those previously described for P. glaucopunctata (Wong et al. 2000; Camara et al. 2001).

Two isolates morphologically identified as P. glaucopunctata were grown on PDA for two weeks at $25^{\circ} \mathrm{C}$. Total genomic DNA was extracted from fungal mycelium with a DNeasy ${ }^{\circledR}$ Plant Mini Kit (Qiagen, Melbourne, Vic., Australia) according to the manufacturer's instructions. Amplification of the ITS1 and ITS2 regions flanking the 5.8S ribosomal RNA gene was carried out with universal primers ITS1 and ITS4 (White et al. 1990). Amplification mixtures contained approximately $100 \mathrm{ng}$ of genomic DNA, 1x Taq DNA polymerase buffer, $1.5 \mu \mathrm{M}$ units Taq DNA polymerase (BioLine, UK). Mixtures were subjected to 1 min at $94^{\circ} \mathrm{C}$ was followed by 30 cycles of $94^{\circ} \mathrm{C}$ for $30 \mathrm{~s}, 56^{\circ} \mathrm{C}$ for $30 \mathrm{~s}, 72^{\circ} \mathrm{C}$ for $1 \mathrm{~min}$ with a final extension of $7 \mathrm{~min}$ at $72^{\circ} \mathrm{C}$ on a thermal cycler (Bio-RAD MJ Mini TM Personal). PCR products $(10 \mu \mathrm{l})$ were visualized on $1 \%(\mathrm{wt} / \mathrm{vol})$ agarose gels containing ethidium bromide. PCR-amplified products were purified using QIAquick
PCR purification kit (Qiagen, Melbourne, Vic Australia) and sequenced with the BigDye terminator cycles sequencing kit (PE Applied Biosystems, Foster City, CA). The products were separated on an ABI 377 DNA sequencer (PE Applied Biosystems, Foster City, CA). The sequences of the ITS1 and ITS2 regions were identical to the sequences from the same region of $P$. glaucopunctata (GenBank Accession No. AF250819). The ITS sequence of one of the two P. glaucopunctata isolates from the current study is deposited in GenBank as accession JN654921.

A pathogenicity test was carried out on the detached leaves of a 3 years old glasshouse grown R.aculeatus using two isolates of $P$. glaucopunctata grown on PDA for 14 days. The pathogenicity test was conducted on both wounded and non-wounded leaves as described by Lee et al. (2005). For the, wounded testing, a single pin-prick wound was made in each of eight leaves using a syringe needle and one mycelial plug (10 $\mathrm{mm}$ in diam.) was placed on each wound. Mycelial plugs were fixed to the wound/pseudo wound sites with parafilm to prevent contamination and desiccation, and then removed after 7 days. Wounded and non-wounded controls (8 leaves) were inoculated using pure agar plugs as described previously. Inoculated leaves were placed in moist trays at $25^{\circ} \mathrm{C}$ with a 12 -h dark and light cycle. The disease symptoms were identical to those observed on the naturally infected material 2 weeks post-inoculation. Symptom development was accelerated on woundinoculated material compared with non-wound-inoculated leaves. Controls remained asymptomatic. Koch's postulates were fulfilled by reisolation of $P$. glaucopunctata. A culture of $P$. glaucopunctata, confirmed via ITS sequencing, is deposited in the Western Australia Plant Pathogen Collection as WAC13408. To our knowledge, this is the first report of $P$. glaucopunctata causing leaf spot and necrosis on $R$. aculeatus in Australia.
Fig. 2 Phaeosphaeriopsis glaucopunctata (teleomorph), asci and ascospores (a, b) and Conyothyrium sp. (anamorph) conidia (c). Bars $=10 \mu \mathrm{m}$
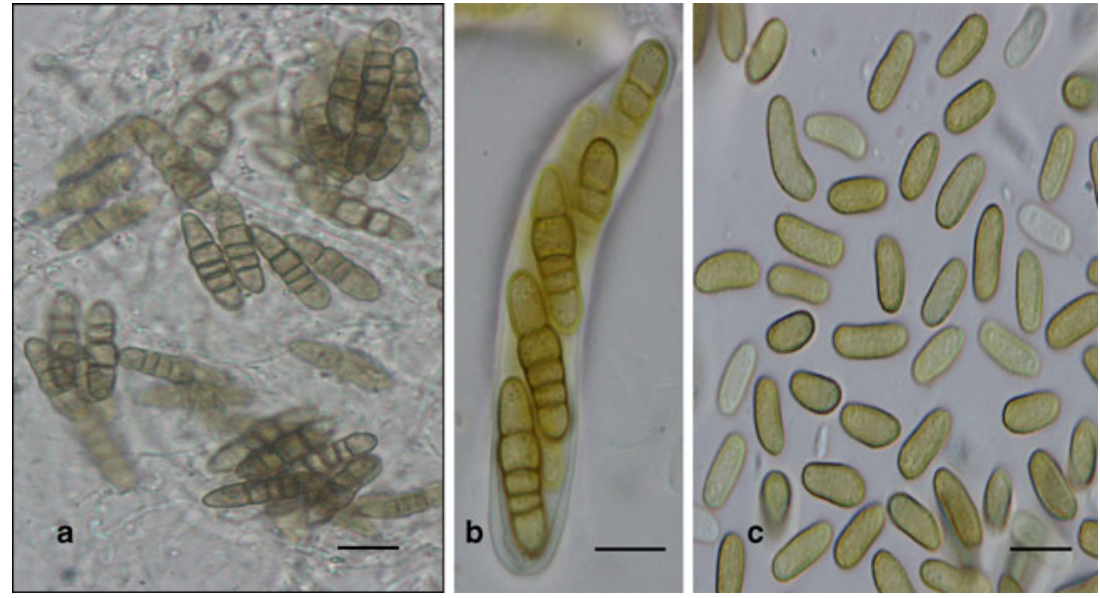
Acknowledgements The authors would like to thank Dr. Roger Shivas from the Queensland Plant Pathology Herbarium, Department of Employment, Economic Development and Innovation for confirming of the identification of the fungus and Ms Paula Mather for technical assistance.

\section{References}

Camara MPS, Palm ME, Berkum PV, Stewart EL (2001) Systematics of Paraphaeosphaeria: a molecular and morphological approach. Mycological Research 105:41-56

Camara MPS, Ramaley AW, Castlebury LA, Palm ME (2003) Neophaeosphaeria and Phaeosphaeriopsis, segregates of Paraphaeosphaeria. Mycological Research 107:516-522
Checa J, Ramaley AW, Palm-Hernandez ME, Camara MPS (2002) Paraphaeosphaeria barrii, a new species on Yucca schidigera from Mexico. Mycological Research 106:375-379

Lee HB, Kim KM and Jung HS (2005) Paraphaeosphaeria recurvifoliae, a new species causing leaf spots and necrosis on Yucca recurvifolia. Fungal Diversity 20:71-81. Available online at www.fungaldiversity.org/fdp/sfdp/FD 20 71-81.pdf

White TJ, Bruns T, Lee S, Taylor J (1990) Amplification and direct sequencing of fungal ribosomal RNA genes for phylogenetics. In: Innis MA, Gelfand DH, Sninsky JJ, White TJ (eds) PCR protocols: a guide to methods and applications. Academic, San Diego, pp 315-322

Wong MKM, Goh TK and Hyde KD (2000). Paraphaeosphaeria schoenoplecti sp. nov. from senescent culms of Schoenoplectus litoralis in Hong Kong. Fungal Diversity 4:171 179 . Available online at www.fungaldiversity.org/fdp/sfdp/FD_4_171-179.pdf 